\section{Prompt Cooling Reduces Incidence and Severity of Decay Caused by Botrytis cinerea and Rhizopus stolonifer in Strawberry}

\author{
M.C.N. Nunes ${ }^{1,2}$, \\ A.M.M.B. Morais ${ }^{1}$, J.K. Brecht ${ }^{3}$, \\ S.A. Sargent ${ }^{3}$, and J.A. Bartz
}

ADDITIONAL INDEX WORDS. forced-air cooling, pressure cooling, cooling delay, Fragaria xananassa

SumMary. Delays in initiating the cooling of freshly harvested 'Chandler' strawberries (Fragaria xananassa) were compared with prompt cooling to determine how such handling affected development of postharvest decays during subsequent storage and marketing. Strawberries at the threequarter to full red ripeness stages were harvested four times between mid-June and late July, inoculated with Botrytis cinerea or Rhizopus stolonifer and then handled to simulate prompt or delayed precooling prior to storage. This was done by incubating fruit at $35{ }^{\circ} \mathrm{C}\left(95.0{ }^{\circ} \mathrm{F}\right)$ and $70 \%$ to $80 \%$ relative humidity $(\mathrm{RH})$ for 1 or 6 hours. The fruit were then forced-air cooled to $5{ }^{\circ} \mathrm{C}\left(41.0^{\circ} \mathrm{F}\right)$ in 1 hour and stored for 7 days at $2{ }^{\circ} \mathrm{C}$ $\left(35.6{ }^{\circ} \mathrm{F}\right)$ and $85 \%$ to $95 \% \mathrm{RH}$, plus displayed in a simulated market at $20^{\circ} \mathrm{C}\left(68.0{ }^{\circ} \mathrm{F}\right)$ and $85 \% \mathrm{RH}$ for $\mathrm{l}$ day. Decay incidence increased as the season progressed. For non-inoculated fruit, prompt cooling reduced the incidence of decay by an average of

This research was supported by the Florida Agricultura Experiment Station and a grant from JNICT (Junta Nacional de Investigação Científica e Tecnológica Portugal), and approved for publication as Journa Series No. R-10171. We thank the Vairão Agricultural Experiment Station, Portugal, for its cooperation in conducting this research.

${ }^{1}$ Present address: Horticultural Sciences Department, University of Florida, IFAS, PO Box 110690, Gainesville, FL 32611-0690.

${ }^{2}$ Escola Superior de Biotecnologia, Universidade Católica Portuguesa, Rua Dr. António Bernardino de Almeida 4200 Porto, Portugal.

${ }^{3}$ Horticultural Sciences Department, University of Florida, IFAS, Gainesville, FL, 32611-0690.

${ }^{4}$ Plant Pathology Department, University of Florida, IFAS, Gainesville, FL 32611-0680.
$25 \%$ and the decay severity by $\sim 24 \%$. With inoculated fruit, prompt cooling resulted in $15 \%$ and $29 \%$ decreases in the incidence and severity, respectively, of rhizopus rot compared to delayed cooling, and $5 \%$ and $22 \%$ decreases in the incidence and severity, respectively, of botrytis rot. Overall, the incidence of botrytis and rhizopus fruit rot averaged $60 \%$ and $85 \%$ in the prompt and delayed cooling treatments, respectively. Although prompt cooling is important for minimizing postharvest decay of strawberries, temperature management alone may not sufficiently control postharvest decay when decay pressure is high.

$\mathrm{C}$ areless handling practices, including mismanagement of storage temperatures, can easily damage strawberry fruit and increase their vulnerability to infection by decay pathogens. Postharvest losses can be extremely high if storage temperature is not properly managed. Strawberries are usually harvested full red, and can rapidly deteriorate if mishandled. Botrytis fruit rot or gray mold (caused by Botrytis cinerea) and rhizopus rot or leak (caused by Rhizopus stolonifer) are the most important fruit rots of strawberry (Maas, 1978, 1992). Ceponis et al. (1987) observed that $B$. cinerea and $R$. stolonifer were present in $\sim 15 \%$ and $4 \%$, respectively, of USDA-inspected strawberry shipments to the New York market. Harvey et al. (1980) also reported that, in truck shipments of California strawberries to New York and Philadelphia, most of the decay was caused by $B$. cinerea. Fruit harvested late in the season can also be more prone to postharvest decay due to increased levels of field infection (Barkai-Golan, 2001).

Botrytis fruit rot is a universal problem wherever strawberries grow. The disease can develop before or after harvest. Postharvest incidences may range up to $30 \%$ to $50 \%$ of the crop (Borecka and Millikan, 1981; Dennis and Davis, 1977; Dennis and Mountford, 1975; Maas, 1978). The minimum growth temperature for the pathogen is about $-2{ }^{\circ} \mathrm{C}\left(28.4^{\circ} \mathrm{F}\right)$ (Sommer et al., 1973). Disease development will continue on cold-stored fruit although progress is most rapid at room temperature, especially if free moisture is present (Ryall and Pentzer, 1982; Sommer, 1992). Infected fruit show a brown discoloration, but even when completely decayed, fruit may preserve their integrity with very little juice exudation. Afterward, the mycelium grows, changing color from white to gray as the sporulation begins (Dennis, 1983; Maas, 1992; Ryall and Pentzer, 1982). Most fruit infection occurs in the field as latent infections of the stem attachment (Powelson, 1960), which usually remains quiescent until the fruit ripens. Additional inoculation and infection are associated with inadvertent wounds occurring during harvest.

Rhizopus rot can also occur in the field, but it is considered primarily postharvest or storage decay. This pathogen is strictly wound invading since the initial infection occurs through breaks, bruises, or abrasions on the fruit surface (Maas, 1992). Sporulation occurs only on fruit lesions. The pathogen appears unable to colonize and then sporulate on plant debris in the field (Dennis, 1983; Ryall and Pentzer, 1982). Spores form freely at favorable temperatures and readily infect injuries on other fruit. Spread of the decay also occurs by contact between decayed and sound fruit. However, infection of fruit from spores or mycelium of $R$. stolonifer will not occur on fruit held at $\leq 5{ }^{\circ} \mathrm{C}$. Diseased fruit usually disintegrate, which releases abundant cell sap, hence the disease descriptor, leak.

Increased postharvest strawberry losses have been associated with cooling delays of as little as $1 \mathrm{~h}$ after harvest (Mitchell, 1992; Mitchell et al., 1996). In fact, Kenny (1979) observed that delaying precooling from 3 to $8 \mathrm{~h}$ after harvest reduced strawberry storage life considerably. However, neither Mitchell et al. (1996) nor Kenny (1979) quantified the decay in their studies. Some delay from harvest to cooling is unavoidable in commercial strawberry operations, as harvested fruit must be accumulated in the field, flats palletized, trucks loaded and driven to the cooling facility, and pallets of fruit finally staged for precooling. Since it is well known that lowering the temperature of fruits after harvest reduces the development of decays in general, it has been recommended that strawberry fruit should be cooled to 0 to $3{ }^{\circ} \mathrm{C}$ $\left(32.0\right.$ to $\left.37.4^{\circ} \mathrm{F}\right)$ as soon as possible after harvest (Mitchell et al., 1996). However, this assumption has not previously been tested to quantify the extent of the assumed benefit in terms of reduced decay development.

That temperature management 
alone is not sufficient to control postharvest strawberry decay is suggested by the widespread use of modified atmosphere (MA) as a supplement to refrigeration during strawberry handling. The most common commercial MA system used in the United States uses a $\geq 10 \% \mathrm{CO}_{2}$-enriched atmosphere within sealed polyethylene pallet covers (Harvey et al., 1980). The main benefit of MA for strawberries is inhibition of decay by the elevated $\mathrm{CO}_{2}$ (Smith, 1992; Woodward and Topping, 1972) and, to a lesser extent, the low levels of $\mathrm{O}_{2}$ used (Borecka and Millikan, 1981; Littlefield et al., 1966).

The objective of this work was to evaluate the effects of a short delay to cooling with fruit harvested during warm weather $\left(35^{\circ} \mathrm{C}\right)$, as might be encountered in normal commercial operations, on the development of decay in 'Chandler' strawberries. Incidence and severity of decay were evaluated after storage for $7 \mathrm{~d}$ at $2{ }^{\circ} \mathrm{C}$ plus a simulated retail display period of $\mathrm{l} \mathrm{d}$ at room temperature $\left(20^{\circ} \mathrm{C}\right)$.

\section{Material and methods}

Plant material. 'Chandler' strawberries were obtained from an agricultural experiment station located in the north of Portugal, at Vairão, Vila do Conde. The strawberries were grown with furrow irrigation in double rows on raised beds covered with black plastic mulch. There were no applications of fungicides or drip irrigation. A total of four harvests (experiments) were conducted during Summer 1993. Strawberries were harvested 13 and 19 June, and 7 and 27 July. Freshly harvested fruit were promptly moved from the field near Vairão to the laboratory in Porto within an average of $1 \mathrm{~h}$ at a temperature of approximately 20 ${ }^{\circ} \mathrm{C}$. Upon arrival, 80 strawberries were immediately selected for uniformity of ripeness (three-quarter to full red, but not overripe) and freedom from defects. Four replicates of five fruit (usually a mixture of the two maturities) each were placed in plastic clamshells and assigned randomly to each treatment or the control in order to simulate commercial harvest and inoculated. The remaining non-inoculated fruit were used as a control.

Fruit inoculation. Cultures of $B$. cinerea or $R$. stolonifer that had been isolated from diseased strawberries were grown on potato dextrose agar (PDA) for $5 \mathrm{~d}$ at $21{ }^{\circ} \mathrm{C}(69.8$ $\left.{ }^{\circ} \mathrm{F}\right)$. The surfaces of the 5 -d cultures were flooded with sterilized tap water containing $0.1 \%$ Tween 20 and then brushed with a bent glass spreader. The resulting suspension was filtered through cheesecloth and then diluted to $10^{5}$ spores $/ \mathrm{mL}$ for either $R$. stolonifer or B. cinerea. Whole fruit were completely submerged in the spore suspensions or water plus surfactant alone (control) for $2 \mathrm{~s}$.

CoOling Delay, COOLING, AND storage CONDitions. Following inoculation, the fruit were placed in a controlled temperature room at 35 ${ }^{\circ} \mathrm{C} \pm 1.0^{\circ} \mathrm{C}\left( \pm 1.8^{\circ} \mathrm{F}\right)$ and $70 \%$ to $80 \%$ $\mathrm{RH}$ with no airflow in order to raise fruit temperatures uniformly to those of fruit harvested during a warm day. Fruit samples were removed from the $35^{\circ} \mathrm{C}$-storage after 1 or $6 \mathrm{~h}$ and immediately transferred to a room at $2{ }^{\circ} \mathrm{C} \pm 0.5{ }^{\circ} \mathrm{C}\left( \pm 0.9{ }^{\circ} \mathrm{F}\right)$ and $85 \%$ to $95 \% \mathrm{RH}$ for forced-air cooling in the "promptly" or "delayed" cooling treatments, respectively. Forced-air cooling was accomplished using a fan that circulated the air within the room and past the baskets of strawberries at $\sim 2$ to $3 \mathrm{~m} \cdot \mathrm{s}^{-1}$ with an air temperature of $\sim 2{ }^{\circ} \mathrm{C}$. Fruit pulp temperatures fell to $5{ }^{\circ} \mathrm{C}$ within $\sim 1 \mathrm{~h}$. The total delay from harvest until the start of cooling was thus either 2 or $7 \mathrm{~h}$ ( $1 \mathrm{~h}$ for transport from the field, sorting and inoculation, plus 1 or $6 \mathrm{~h}$ delay at $35^{\circ} \mathrm{C}$ ). After cooling, the strawberries were then stored in the dark at $2{ }^{\circ} \mathrm{C} \pm 0.5$ ${ }^{\circ} \mathrm{C}$ and $90 \%$ to $95 \% \mathrm{RH}$ for $7 \mathrm{~d}$. After $2{ }^{\circ} \mathrm{C}$ storage, the fruit were moved to $20^{\circ} \mathrm{C} \pm 1.0^{\circ} \mathrm{C}$ and $85 \% \mathrm{RH}$ for $\mathrm{ld}$ to simulate a retail market display.

Decay evaluation. Decay incidence or number of fruit with distinctive lesions of gray mold and/or rhizopus rot was recorded after simulated retail display. Disease severity was also recorded after the simulated retail display based on a 1 to 5 scale, where $\mathrm{l}=$ no visible changes in the tissues; 2 = slight brown discoloration of the tissues; 3 = slight to moderate mycelium growth; $4=$ moderate to heavy mycelium growth; 5 = characteristic sporulation. The severity scale was converted to a percentage of full sporulation such that $1=0 \% ; 2=25 \% ; 3=$ $50 \% ; 4=75 \%$; and $5=100 \%$.

Statistical analysis. The percentage of full sporulation (severity of rhizopus or botrytis fruit rot) at the surface of the fruit was transformed by the arcsin square root method using radians. The transformed variables were analyzed with the SAS computer package (SAS Institute, 1982) software by a three-way analysis of variance (ANOVA), with harvest, inoculated pathogen, and delay to cooling as factors. A Fisher's protected least significant difference (LSD) $(P \leq 0.05)$ was applied to the transformed values.

\section{Results and discussion}

Inoculation ( $R$. stolonifer or $B$. cinerea) significantly increased decay incidence $(P<0.01)$ and severity $(P$ $<0.001$ ). The cooling treatment (i.e., delay) also significantly affected decay incidence $(P<0.001)$ and severity $(P$ $<0.001$ ) with less decay and reduced severity occurring in the promptly cooled fruit (Figs. 1 and 2). The benefits of prompt cooling occurred after each harvest and with both pathogens. There was an average $25 \%$ less decay incidence in non-inoculated strawberries from the prompt cooling treatment than from the delayed cooling treatments after $7 \mathrm{~d}$ at $2{ }^{\circ} \mathrm{C}$ plus $1 \mathrm{~d}$ at $20^{\circ} \mathrm{C}$ (Fig. 1). For fruit that were inoculated with $R$. stolonifer, rhizopus rot incidence was $80 \%$ and $90 \%$ for promptly cooled fruit in the first and third harvests, respectively, compared to $100 \%$ after delayed cooling (Fig. 1). For fruit that were inoculated with $B$. cinerea, decay incidence increased from $90 \%$ to $95 \%$ in the second harvest and from $95 \%$ to $100 \%$ in the fourth harvest for the prompt and delayed cooling treatments, respectively (Fig. $1)$. Strawberries inoculated with $R$. stolonifer that were cooled promptly had lower incidence of decay than strawberries inoculated with $B$. cinerea and promptly cooled (Fig. 1). In fact, prompt cooling reduced the incidence and severity of rhizopus rot in inoculated fruit by $15 \%$ and $29 \%$ for harvests 1 and 3, respectively, compared with $5 \%$ and $22 \%$ reduction in incidence and severity of gray mold in harvests 2 and 4 , respectively (Figs. 1 and 2 ).

Although growth of germinated rhizopus spores is inhibited at temperatures below $6^{\circ} \mathrm{C}\left(42.8^{\circ} \mathrm{F}\right)$ (Maas, 1992), strawberries from the present study stored at $2{ }^{\circ} \mathrm{C}$ showed a relatively high incidence of rhizopus rot (Fig. 1). Ceponis et al. (1987) reported that rhizopus rot affected $13 \%$ of the fruit in evaluated strawberry shipments on the New York market. Ferreira et al. (1996) reported no incidence of rhizopus rot in Florida-grown 'Chandler' strawber- 


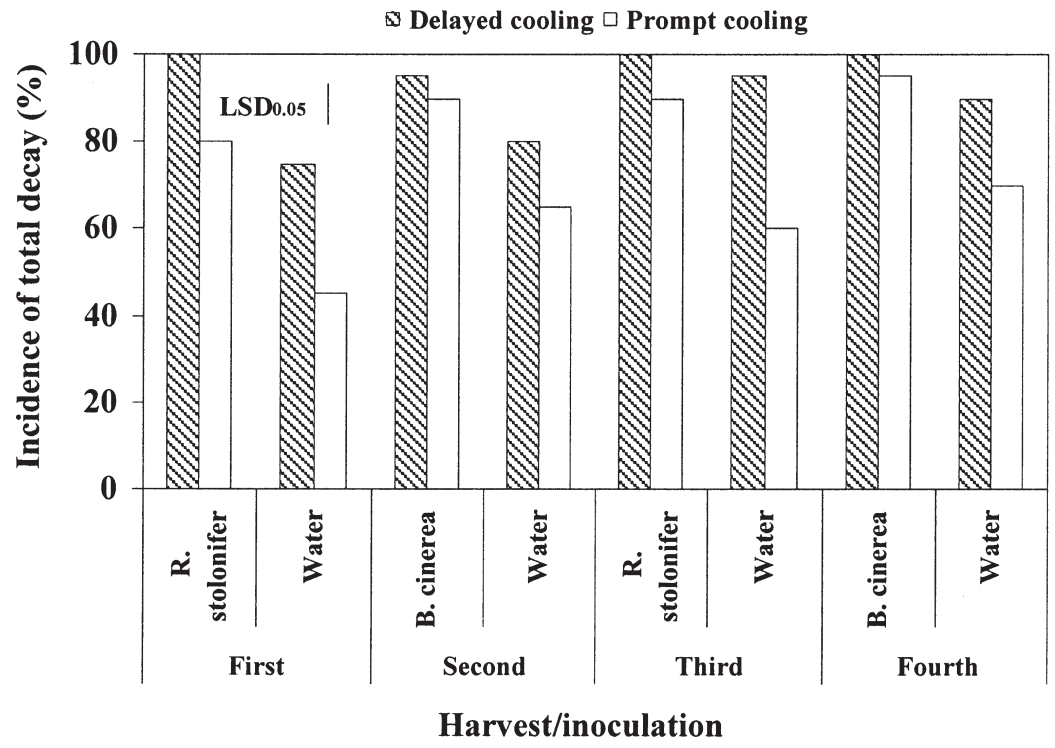

Fig. 1. Effects of delayed cooling on the incidence of total postharvest decay of strawberries that had been dipped in a conidial suspension of Rbizopus stolonifer or Botrytis cinerea at $10^{5}$ spores $/ \mathrm{mL}$ or dipped in water, stored for 1 week at 2 ${ }^{\circ} \mathrm{C}$ and $85 \%$ to $95 \%$ relative humidity $(\mathrm{RH})$, and finally examined after $24 \mathrm{~h}$ in a simulated consumer display at $20^{\circ} \mathrm{C}$ and $85 \% \mathrm{RH}$. Delayed cooling $=6 \mathrm{~h}$ after inoculation; prompt cooling $=1 \mathrm{~h}$ after inoculation.

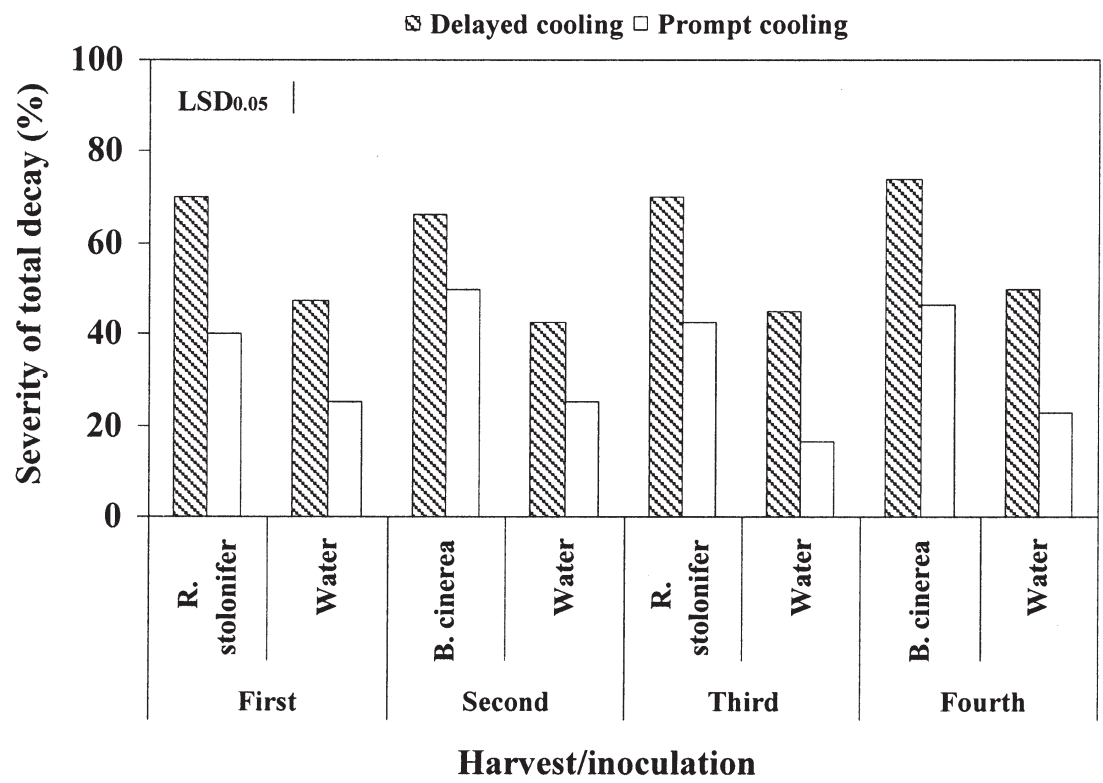

Fig. 2. Effects of delayed cooling on the severity of total postharvest decay of strawberries that had been dipped in a conidial suspension of Rhizopus stolonifer or Botrytis cinevea at $10^{5}$ spores $/ \mathrm{mL}$ or dipped in water, stored for 1 week at 2 ${ }^{\circ} \mathrm{C}$ and $85 \%$ to $95 \%$ relative humidity $(\mathrm{RH})$, and finally examined after $24 \mathrm{~h}$ in a simulated consumer display at $20^{\circ} \mathrm{C}$ and $85 \% \mathrm{RH}$. Delayed cooling $=6 \mathrm{~h}$ after inoculation; prompt cooling $=1 \mathrm{~h}$ after inoculation.

ries stored at $7{ }^{\circ} \mathrm{C}\left(44.6^{\circ} \mathrm{F}\right)$ for $11 \mathrm{~d}$. The higher incidence and severity of rhizopus rot observed in strawberries in the present study compared to reports in the literature could have been a result of several factors. The duration of the delay to cooling and the temperature during the delay probably favored rhizopus rot development (Dennis and
Cohen, 1976). Exposure of the fruit to free water during the inoculation procedure may also have facilitated contamination of wounds and other openings on the fruit surface, leading to greater decay incidence and severity. Ferreira et al. (1996) used fruit with pulp temperature of $24^{\circ} \mathrm{C}\left(75.2^{\circ} \mathrm{F}\right)$ for their precooling experiments, while in the present study the temperature of the fruit had reached $\sim 30^{\circ} \mathrm{C}\left(86.0^{\circ} \mathrm{F}\right)$ before cooling. Incidence and severity of rhizopus rot would also be expected to increase in the present study due to the additional day at $20^{\circ} \mathrm{C}$.

The incidences of botrytis rot observed here were also higher than those reported by other authors (Ceponis et al., 1987; Sommer et al., 1973). For example, Sommer et al. (1973) observed a maximum of $12.9 \%$ gray mold rot in non-inoculated strawberries after a transport by truck of $90 \mathrm{~h}$ at $5.3^{\circ} \mathrm{C}\left(41.5^{\circ} \mathrm{F}\right)$ from Watsonville, Calif., to Atlanta, Ga. However, those strawberries were grown in commercial fields with fungicide applications and had been immediately forced-air cooled to $1.5^{\circ} \mathrm{C}\left(34.7^{\circ} \mathrm{F}\right)$ to $2^{\circ} \mathrm{C}$ in a nearby cooling facility (compared to cooling to $5^{\circ} \mathrm{C}$ starting 2 or $7 \mathrm{~h}$ after harvest in our work). The transportation period in Sommer et al. (1973) was also much shorter than the storage duration used here, and they did not include a simulated 24 -h retail display regime. Thus, the handling procedures used here were more favorable to disease development than were those of Sommers et al. (1973). Ceponis et al. (1987) reported that gray mold rot was the most common decay in strawberry shipments on the New York market for which USDA inspections were requested, as it occurred in $76 \%$ of the strawberry shipments evaluated and affected more than $10 \%$ of the fruit in almost half of the affected shipments. In a previous study in our laboratory in Florida, Ferreira et al. (1996) reported 43\% decay incidence in 'Chandler' strawberries held for 6 $\mathrm{h}$ at $30^{\circ} \mathrm{C}$ prior to hydrocooling and stored at $7^{\circ} \mathrm{C}$ for $11 \mathrm{~d}$.

Although temperatures higher than $40{ }^{\circ} \mathrm{C}\left(104.0^{\circ} \mathrm{F}\right)$ can effectively reduce postharvest decay caused either by $R$. stolonifer or B. cinerea (Smith and Worthington, 1965), temperatures between 20 and $35^{\circ} \mathrm{C}$ generally promote rapid pathogen development (Sommer, 1992). This suggests that the temperature of the strawberries during the delay to cooling in our study, during which the fruit warmed from 20 to 30 ${ }^{\circ} \mathrm{C}$, was quite conducive to decay establishment and probably favored greater decay development during subsequent storage. The additional day at $20^{\circ} \mathrm{C}$ used in our study, which simulated a retail display, also contributed to the increased incidence and severity of 
decay in strawberries either from the prompt cooling or delayed cooling treatments.

Promptly cooled, non-inoculated strawberries from the third and fourth harvests showed a higher incidence of decay than those from the earlier harvests (Fig. 1). The same effect was not observed for fruit from the delayed cooling treatment or for inoculated fruit, both of which had higher overall decay incidence than non-inoculated fruit. Increased decay incidence in later harvests could be a consequence of higher inoculum levels and latent infections in the field, which generally increase as the growing season progresses (Dennis and Davis, 1977; Dennis and Mountford, 1975). Occurrence of infection by B. cinerea and $R$. stolonifer has been reported to be greater on strawberry fruit harvested late in the season, and it has been suggested that late season fruit might be more susceptible to attack by these spoilage fungi (Dennis and Davis, 1977; Dennis and Mountford, 1975). This may be a general occurrence as, for example, Lallu et al. (2000) reported that in late-harvested asparagus, the incidence of tip rot after 3 weeks storage was higher than in spears from an early harvest. In most strawberry-producing regions of the world, field temperatures increase as the season progresses and, in subtropical regions (like in Florida), late season rains are also more frequent, both of which would favor increased fungal infection.

Delaying the start of cooling greatly increased the severity of decay for both inoculated and non-inoculated strawberries (Fig. 2), indicating that growth of the pathogens during storage was more rapid in the fruit that were held at $35^{\circ} \mathrm{C}$ for $6 \mathrm{~h}$ before cooling. For non-inoculated fruit, prompt cooling reduced the incidence of decay by an average of $25 \%$ and the decay severity by $\sim 24 \%$. In addition, fruit from the delayed cooling treatment senesced more rapidly than those from the prompt cooling treatment, which might have also contributed to an increased susceptibility to decay. In fact, Pritts et al. (1987) noted that susceptibility to fungal attack increased as strawberries senesced.

\section{Conclusions}

Postharvest decay of strawberries caused by $B$. cinerea and $R$. stolonifer constitutes a serious problem because fruit losses can lead to loads being rejected upon arrival at destination. In addition, a short delay before cooling caused on average an increase of $18 \%$ and $30 \%$ in the incidence and severity, respectively, of strawberry decay when compared with fruit that were cooled promptly. This study affirms the assumption that to reduce the extent of decay problems, prompt precooling after harvest and subsequent storage at low temperature constitute important steps in order to retard development of strawberry fruit rots and to maintain acceptable fruit appearance. Our results clearly show, however, that prompt cooling and storage at $2{ }^{\circ} \mathrm{C}$ alone are not sufficient to control strawberry postharvest decay, at least in the face of severe disease pressure, as was the case in this study.

\section{Literature cited}

Barkai-Golan, R. 2001. Postharvest diseases of fruits and vegetables. Development and control. Elsevier, Amsterdam.

Borecka, H. and D.F. Millikan. 1981. Influence of storage conditions upon the development of postharvest gray-mold rot of strawberries. Phytoprotection 62:11-16.

Ceponis, M.J., R.A. Cappellini, and G.W. Lightner, 1987. Disorders in sweet cherry and strawberry shipments to the New York market, 1972-1984. Plant Dis. 71:472-475.

Dennis, C. 1983. Soft fruits, p. 23-42. In: C. Dennis (ed.). Post-harvest pathology of fruits and vegetables. Academic Press, New York.

Dennis, C. and E. Cohen. 1976. The effect of temperature on strains of soft fruit spoilage fungi. Ann. Appl. Biol. 8(21):51-56.

Dennis, C. and R.P. Davis. 1977. Susceptibility of strawberry varieties to post-harvest fungal spoilage. J. Appl. Bacteriology 42:197-206.

Dennis, C. and J. Mountford. 1975. The fungal flora of soft fruits in relation to storage and spoilage. J. Appl. Biol. 79:141-147.

Ferreira, M.D., J.A. Bartz, S.A. Sargent, and J.K. Brecht. 1996. An assessment of the decay hazard associated with hydrocooling strawberries. Plant Dis. 80:1117-1122.

Harvey, J.M, C.M. Harris, W.J. Tietjen, and T. Seriol. 1980. Quality maintenance in truck shipments of California strawberries. Adv. Agr. Technol. AA-W-12, U.S. Dept. Agr., Washington, D.C

Kenny, T.A. 1979. Studies on precooling soft fruits, strawberries. Irish J. Food Sci. Technol. 3:19-31.

Lallu, N., C.W. Yearsley, and H.J. Elgar. 2000. Effects of cooling treatments and physical damage on tip rot and postharvest quality of asparagus spears. N.Z. J. Crop Hort. Sci. $28: 27-36$.

Littlefield, N.A., B.N. Wankier, D.R. Salunkhe, and J.N. McGill. 1966. Fungistatic effects of controlled atmosphere. Appl. Microbiol. 14:579-580.

Maas, J.L. 1978. Screening for resistance to fruit rot in strawberries and raspberries: A review. HortScience 13:423-426.

Maas, J.L. (ed.). 1992. Compendium of strawberry diseases. APS Press and Agr. Res. Serv., U.S. Dept. Agr., St. Paul, Minn.

Mitchell, F.G. 1992. Postharvest handling systems: Small fruits (table grapes, strawberries, kiwifruit), p. 223-231. In: A.A. Kader (ed.). Postharvest technology of horticultural crops. Publ. No. 3311. Univ. of California Div. Agr. Natural Resources, Oakland.

Mitchell, F.G., E.C. Maxie,. and A.S. Greathead. 1996. Handling strawberries for fresh market. Publ. No. 2442. Univ. of California Div. Agr. Natural Resources, Oakland.

Powelson, R.L. 1960. Initiation of strawberry fruit rot caused by Botrytiscinerea. Phytophatology 50:491-494.

Pritts, M.P., J.A. Barscht, K.A. Worden, and M.C. Jorgensen. 1987. Factors influencing quality and shelf life of strawberry cultivars in the eastern United States. Adv. Strawberry Production 6:14-17.

Ryall, A.L. and W.T. Pentzer. 1982. Diseases and injuries of small fruits during marketing, p. 519-547. In: A.L. Ryall and W.T. Pentzer (eds.). Handling, transportation and storage of fruits and vegetables. Fruits and tree nuts. Vol. 2. 2nd ed. AVI Publ. Co., Westport, Conn.

SAS Institute. 1982. SAS user's guide: Statistics. SAS Inst., Cary, N.C.

Smith, R.B. 1992. Controlled atmosphere storage of 'Redcoat' strawberry fruit. J.Amer. Soc. Hort. Sci. 117:260-264.

Smith, W.L. Jr. and J.T. Worthington. 1965. Reduction of postharvest decay of strawberries with chemical and heat treatments. Plant Dis. Rptr. 49:619-623.

Sommer, N.F. 1992. Principles of disease suppression by handling practices, p. 109-116. In: A.A. Kader (ed.). Postharvest technology of horticultural crops. Publ. No. 3311 . Univ. of California Div. Agr. Natural Resources, Oakland.

Sommer, N.F., R.J. Fortlage, F.G. Mitchell, and E.C. Maxie. 1973. Reduction of postharvest losses of strawberry fruits from gray mold. J. Amer. Soc. Hort. Sci. 98:285-288.

Woodward, J.R. and A.J. Topping. 1972. The influence of controlled atmospheres on the respiration rates and behavior of strawberry fruits. J. Hort. Sci. 47:547-553. 